\title{
LAMA3 Gene
}

National Cancer Institute

\section{Source}

National Cancer Institute. LAMA3 Gene. NCI Thesaurus. Code C137975.

This gene is involved in cell-matrix adhesion and cell migration. 